\title{
Socio-scientific issues implementation as science learning material
}

\author{
Marlina Ummas Genisa ${ }^{1,2}$, Bambang Subali ${ }^{3}$, Djukri ${ }^{4}$, Andi Agussalim ${ }^{5}$, Habibi Habibi ${ }^{6}$ \\ ${ }^{1}$ Educational Graduate School, Yogyakarta State University, Indonesia \\ ${ }^{2}$ Biology Education Department, Muhammadiyah University of Palembang, Indonesia \\ ${ }^{3,4}$ Natural Science Department, Yogyakarta State University, Indonesia \\ ${ }^{5}$ Faculty of Mathematics and Natural Sciences, Sriwijaya University of Palembang, Indonesia \\ ${ }^{6}$ Physics Education, Universitas Pendidikan Mandalika, Indonesia
}

\section{Article Info}

Article history:

Received Feb 11, 2020

Revised Mar 20, 2020

Accepted Apr 2, 2020

\section{Keywords:}

Exploration

Mapping

Science learning

Socio-scientific issues

\begin{abstract}
This paper analyzes the implementation of socio-scientific issues (SSI) as an alternative in science learning. The content analysis approach is used for mapping implementation of social-scientific problems around the world and is created using the ArcGIS 10.5 program. The findings highlight how the distribution patterns of SSI implementation are dominated by argumentation and decision making in SSI research. Teacher professional development related to SSI implementation also showed positive results for planning, developing, and solving problems related to SSI instruction. This study contributes as literature in exploring the implementation of SSI in educational contexts because its integration in science teaching materials is unfamiliar.
\end{abstract}

\section{Corresponding Author:}

Marlina Ummas Genisa, Educational Graduate School, Yogyakarta State University, Jl. Colombo No.1, Karang Malang, Sleman, D. I. Yogyakarta, Indonesia. Email: marlina.ummas2016@student.uny.ac.id

\section{INTRODUCTION}

The demand for the literacy of science and technology is based on the idea that technology in today's society requires a number of professionals who can participate in modern science technology today. As an action to support that fulfillment, science literacy becomes one of the main objectives of science learning that requires students to know and apply their knowledge as part of the learning experience. Science literacy is not limited to knowing scientific ideas or facts or being able to participate in any kind of investigation. More than that is the desire and ability to make decisions and take action in daily routine life by every member of the community. According to this perception, science learning in schools and universities must be accessible to all, interpersonal, relevant and useful, regardless of gender, multicultural, humanist and full of value [1]. In other words, science learning should be a part of people's lives, taking place in a variety of settings involving students and community members in activities that benefit their own lives. Thus, the application of learning that involves the aspects of science and society can be a potential learning alternative in promoting science literacy.

Innovative learning in the classroom with methods and strategies that cover all dimensions of science literacy ie content, process and context become an important part of realizing it. The research has shown a new trend in science education by introducing research-based frameworks that encourage explicitly 
integrated socio-scientific issues (SSI) to promote the importance of science literacy [2, 3]. SSI is complex and has no definite solution, based on science, and cannot be solved only with science knowledge but involves various social aspects and must be solved through the integration of aspects, and perspectives [4]. In other word, SSI is a scientific issue but has an impact on society that causing controversy and ethical dilemmas. SSI enables students to view science realistically by integrating attitudes and ethics in making judgments about scientific information, in accordance with the demands of today's society, in line with the curriculum of science learning in Europe, as well as following major trends in science learning [5, 6]. However, although SSI is controversial, not all controversial issues are considered SSI. The SSI framework utilizes informal discussions, formal debates, and argumentative thought as an important part in preparing students to use information in a personally relevant and relevant context. For this reason, many international educators are beginning to integrate SSI into science learning to foster the development of social awareness and develop scientific thinking habits [7]. The raised SSI generally deals with issues that occur in the community, such as environmental pollution and genetically modified foods. In Indonesia itself, SSI content has begun to be integrated from the application in the classroom to the development of teaching materials that support its application, although still in limited quantities.

In the application of learning with integration, SSI found some obstacles such as limited time, the dominance of teaching tends to the scientific knowledge or the reluctance of science teachers to teach issues that are not always compatible with education at schools and universities. SSI puts teachers to organize classes differently through arguments, value-laden discussions that may be unusual for teachers [8]. Furthermore, according to [9], resource constraints in applying SSI and time studies in preparing teaching cause teachers to focus on the objective and factual aspects of science. In addition, awareness of the limitations of knowledge in responding to student ideas on learning SSI can cause problems for teachers and students. This further limits the students to engage in high-level thinking which is key in science literacy. Therefore, training is needed that can provide opportunities for teachers to develop their pedagogical skills to implement SSI based instruction.

The successful implementation of SSI-based teaching has been seen in one of the collaborative activities of lecturers in applying Lesson Study (LS). Lesson study (LS) was introduced to provide coaching or teachers training as a step in improving teacher performance when conducting learning activities. LS involve a group of teachers who meet periodically (months to a year) to: design, implement, test, and improve one or more research studies [10]. LS have been proven to improve teacher quality, learning outcomes and teacher professionalism in Japan and Indonesia [11]. It is interesting to learn about how to apply SSI as an alternative in science learning, while Lesson Study as an innovation to improve teachers' abilities in developing and implementing SSI-based learning.

\section{RESEARCH METHOD}

A systematic literature review was conducted in order to identify the implementation socio-scientific issues as science teaching and learning material and how the different phases are involved in the learning process. The EBSCO host Library (www.ebscohost.com) database was used to search for articles using the search terms: inquiry phases, inquiry stages, inquiry cycle, inquiry models, inquiry learning processes, inquiry-based learning. The search was limited to the term 'inquiry' in different contexts since it was important to focus on how this particular and widely used term had been used in several policy documents [12-14] or in national curricula. The EBSCO host Library was selected because this database has meta-data of more than 64,000 journals, 6 million books, and 400,000 conference proceedings. This exceeds the numbers in Scopus or ISI Web of Knowledge. In the following sections, an overview of the search and data analysis processes is presented.

This study is a content analysis of SSIs related to the implementation of socio-scientific issues published from 2010 to 2018 across the world. The distribution of SSIs related to the implementation of socio-scientific was mapped by using the ArcGIS 10.5 program. It is one of the GIS tools for creating a map, visualizing geospatial data, and analyzing mapped information. Content analysis is a commonly used method in qualitative studies.

\section{RESULTS AND DISCUSSION}

According to Aikenhead [15] in the last few decades, SSI has become a major theme in the science education literature. Various approaches are developed that aim to prepare learners to engage in discussing and making decisions on social issues related to science, for example, researchers exploring concept formation in particular with regard to how the SSI approach can support science literacy. Other researchers focusing on reasoning and decision making in the context of SSI [16], the relationship between SSI decision-

Int. J. Eval. \& Res. Educ. Vol. 9, No. 2, June 2020: 311 - 317 
making with an understanding of the nature of science or content knowledge [17], explores related issues with assessment of learning outcomes of SSI and as part of important classroom learning. The research contributes significantly to science education for the community which demonstrates that the diverse approaches associated with SSI become one of the main focuses of alternative science learning that has been developed to improve student competence.

Figure 1 shows the various issues of SSI research results in various countries in the world. The issues are as follows: the environmental management issue of an invasive species, and reservoir in Taiwan [18, 19], nuclear in Korea [20], environmental pollution in Indonesia [21, 22], health, environmental, whaling, and biodiversity in Sweden [23-26], climate change, energy, genetical manipulation in Germany [27-29], biology, genetics, and democratic in the US [30, 31], genetic manipulation in food in the Midwest and Denmark [32, 33], biology in the UK [34-36], cloning and genetic screening in Australia [37], biotechnology in Florida [38], Energy in Spain [39].

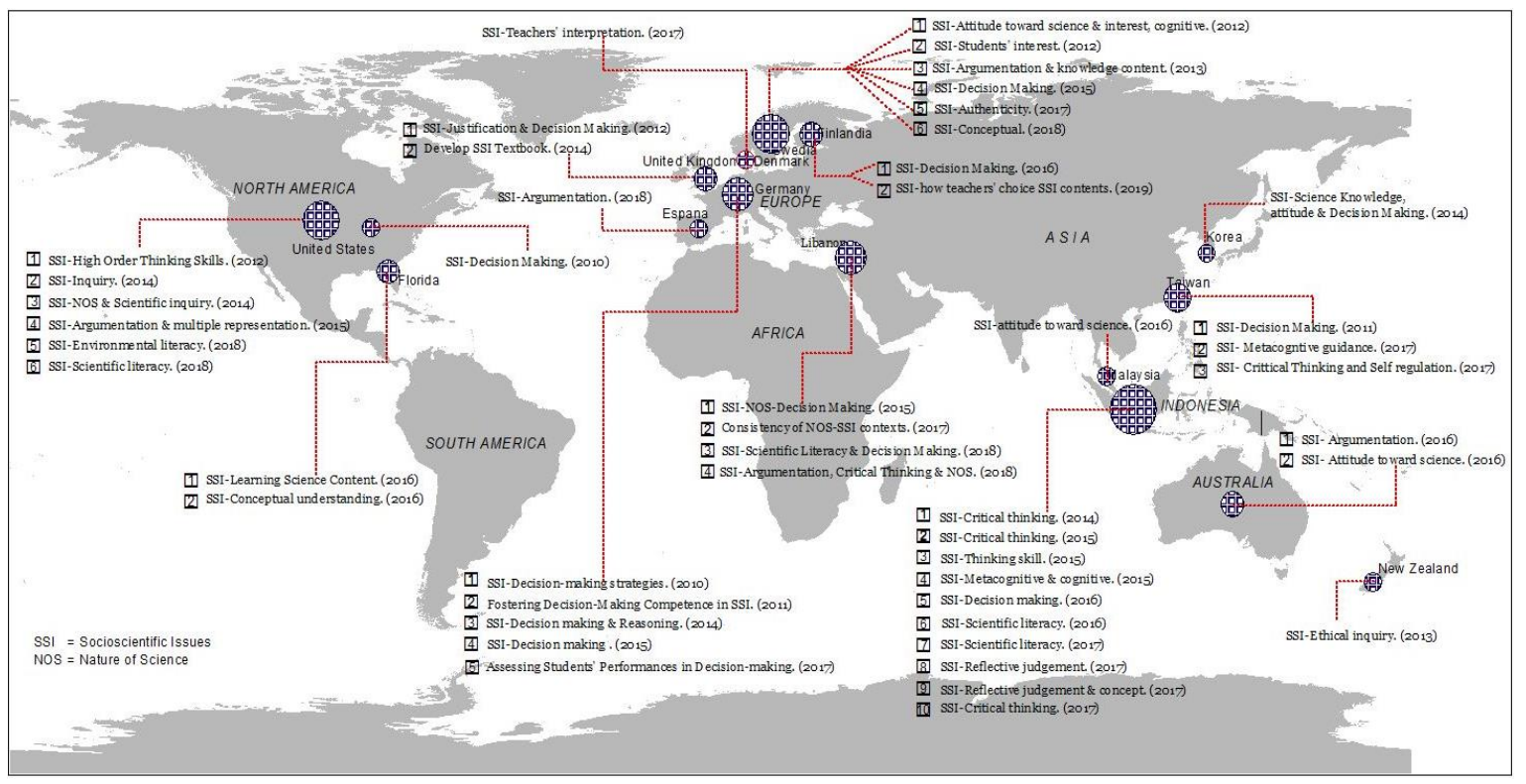

Figure 1. Map of research distribution related to SSI across the world

\subsection{Distribution of SSI implementation}

Research related to SSI has been widely practiced. The results of the analysis of articles published within a span of seven years show the distribution patterns of SSI applications. Most of the research in developed countries such as the United States, Germany, Sweden, and Japan. Several applications of SSI are as follows: as a learning strategy, development of teaching materials for the application of SSI classes, arguments, critical thinking, decision making, and development of SSI assessments (Figure 1). In addition, the research topic is dominated by research on argumentation and decision making that shows positive results for students. This is consistent with the literature study conducted by Tekin [40] in identifying SSI research trends published by five journals with the highest impact factors related to SSI. Research related to SSI increased regularly with the highest publications in 2012 where most were dominated by the application of SSI to improve argumentation and decision making. In addition, according to Siribunnam [41] as a result of database investigations on ERIC, Springer, EBSCOHOST, and ThaiLIS, related to SSI decision making that the first concentration on teaching, reasoning processes in decision making, and decision making frameworks. This finding shows that SSI internationally has received special attention in science education, more specifically regarding SSI decision making and arguments.

The application of SSI varies in different countries and various cultures or traditions. Therefore, problems related to SSI that arise in one country just do not exist in other countries [42]. However, there is no literature that clearly explains social or regional variations in the SSI concept. Indonesia as a developing country also has various phenomena and problems that mig ht not be classified as SSI in other countries. Research that applies SSI was conducted in 2014 through the development of SSI learning tools that improve student thinking skills but are still limited. Over the next few years, SSI research has begun to explore student decision making and arguments in classroom learning as has been studied in other countries. 
Learning in the context of SSI that has been done on an international and local scale shows that SSI contributes positively in improving student skills such as critical thinking skills [43], argumentation [44-46], and decision making [47, 48] which are important in realizing students who are science literacy [49] according to the demands of 21 st century learning. In addition, it is feasible to apply it in classroom such as in Indonesia which has SSI complexity because it consists of diverse cultures and traditions. Therefore, involvement in SSI will train students to participate as citizens in providing solutions for various problems.

\subsection{Socio-scientific issues among countries}

Socio-scientific issues can range from personal to societal. Personally, affects daily life and socially focused on society and global level. As mentioned in the previous point that SSI within a country varies depending on geographical conditions, the characteristics of an area and the development of the country. Based on analysis of SSI raised in the article, obtained a description that the countries in Asia are generally raised the issue related to the problem of environmental pollution. More specifically in Indonesia in conducting SSI teaching and learning, issues raised tend to be related to subjects in schools or universities such as environmental pollution, heat and systems reproduction.In Indonesia, the type of issues raised are personal as well as social, such as the use of food additive, but issues related to the development of technology in society is still not completely visible, except in Korea as one of the developed countries located in Asia has raised issue concerning nuclear power plants as SSI. In other words, although it is still on the same continent, the development of a country influences an emerging issue.

Meanwhile, European countries such as Sweden, UK and Germany dominated issues related to more diverse environmental issues such as environmental pollution, climate change, fishing and biodiversity. In addition, the issue of genetic engineering both in humans and food. Based on the character issues raised are categorized as complex issues. This is evident from the scope of issues raised not only personal, but also the global level which affects the public in general and in a broader scope. It is also seen that the issues raised connect many aspects the development of technology and human health. The mainly reason is because Sweden, Britain and Germany are developed countrieswith developments in many sectors. Countries in America as well as countries in Europe also raised environmental issues as dominant issues such as pollution and disease, ocean, genetic engineering and biotechnology. Based on the character of the issue is included in complex issues related to various aspects and their implications on a wide scale.

Based on the issues that have been analyzed, it can be seen that the similarity of issues between Asia, Europe and America are the issues related to ecological content such as environmental pollution, global warming, ecosystem and biodiversity as popular issues to be adopted as SSI. This is because environmental issues are not merely national issues but also global issues and hence must be tackled with international efforts and cooperation. The impact of environmental issues also causes enormous harm to human health. In addition, the characteristics of env ironmental issues are multidisciplinary that combines several branches of science such as chemistry, physics, medical sciences, life sciences, agriculture, public health, sanitary engineering etc. Therefore, discussing environmental issues allows students to link various aspects that are in line with SSI that not only based on science.

\subsection{Lesson study for applying socio-scientific issues}

The teacher is one factor that contributes to the successful implementation of SSI. The teacher's challenge is how to design lessons and apply. Trends in research show that teachers still find it difficult to apply SSI and most do not include problems in their teaching [50]. It was explained that there was a lack of resources in implementing SSI learning including teaching materials and time to prepare lessons [51]. Some teachers argue that the most important task is to teach the principles of science and try to apply them in the classroom, rigid science curriculum, and conflicting syllabus [52]. In addition, the teacher's limitations and concerns are related to his capacity to respond to students' ideas. This is detrimental to students and teachers, thus limiting the assessment criteria in assessing the ability of SSI learning. Providing some regular training for teachers is very important as a solution.

Lesson study (LS) has been applied in Japan since the 1870s which focuses on the professional development of teachers. LS involve a group of teachers who collaborate in planning [53], teaching [54, 55], observing [56], and analyzing results [57]. Teachers can develop their abilities through collaboration among educators. Learning together can develop teacher competency [58].

The teacher can develop student-centered learning plans from the results of need-analysis and problems in implementing SSI learning such as how to teach and find collaborative solutions. Furthermore, the implementation of SSI learning can practice learning plans together, while other teachers are observers. Reflections on teaching practices need to be part of the evaluation of further teaching. Through LS, teachers are expected to develop skills to maximize SSI application. 
The study of SSI in learning is still rarely applied. Most SSI implementations focus on implementing student learning, while teacher training in teaching SSI is still rare. The results of identification in Indonesia found that SSI as a lesson study was applied to prospective teachers, while in Australia and America there was one about lesson study. Lesson Study is very important to be applied to improve teacher understanding and skills in planning and developing SSI learning.

\section{CONCLUSION}

The implementation of SSI mostly conducted in developed countries which commonly focused on fostering students' argumentation and decision making. These findings suggest that internationally SSI has gained special attention in science education. In Indonesia, SSI is beginning to be studied, but it is still limited. Environmental factors and the development of a country's society also contribute to the emergence of issues or phenomena categorized as SSI. Therefore, SSI problems in a country may not be categorized as SSI in other countries. This is supported by the analysis of SSI issues in several countries in Asia, America and Europe. The issues and characteristics of different issues depend on the situation of country, but generally the issue of ecology is a popular issue to be raised.This is mainly because environmental issues are not merely national issues but also global issues and hence must be tackled with international efforts and cooperation

The successful integration of science learning in the classroom is inseparable from the teacher's ability to apply it. Therefore the teacher plays an important role in this matter. The development of collaborative teacher professionalism in planning, teaching, observing, analyzing learning, and teaching is very important. The teacher must be able to plan student-centered learning based on SSI learning. The application of SSI as a Lesson study in several countries is still rare, therefore, being one aspect that needs more attention.

\section{ACKNOWLEDGEMENTS}

This research was supported and funded by the Education Fund Management Institution (LPDP) of the Ministry of Finance of the Republic of Indonesia, which is led through The Indonesian Lecturer Leading Scholarship.

\section{REFERENCES}

[1] Tal, T. and Kedmi, Y., "Teaching socioscientific issues: Classroom culture and students' performances," Cultural Studies of Science Education, vol. 1, no. 4, pp. 615-644, 2006.

[2] Zeidler, D. L. (Ed.), The role of moral reasoning on socioscientific issues and discourse in science education, vol. 19, Springer Science \& Business Media, 2003.

[3] Zeidler, D. L., Sadler, T. D., Simmons, M. L., and Howes, E. V., "Beyond STS: A research-based framework for socioscientific issues education," Science Education, vol. 89, no. 3, pp. 357-377, 2005.

[4] Eggert, S. and Bögeholz, S., "Students' use of decision-making strategies with regard to socioscientific Issues: An application of the rasch partial credit model," Science Education, vol. 94, no. 2, pp. 230-258, 2010.

[5] Burek, K., and Zeidler, D. L., "Seeing the forest for the trees! Conservation and activism through socioscientific issues," EcoJustice, citizen science and youth activism, Springer, Cham, pp. 425-441, 2015.

[6] Chang, H. and Lee, H., "College Students Decision-Making Tendencies in the Context of Socioscientific Issues (SSI )," J Korea Assoc. Science Education, vol. 30, no. 7, pp. 887-900, 2010.

[7] Zeidler, D. L., Sadler, T. D., Applebaum, S., Callahan, B. E., Education, C., Florida, S., and Avenue, E. F., "Advancing Reflective Judgment through Socioscientific Issues School of Teaching and Learning," College of Education, University of Florida, vol. 46, no. 1, pp. 74-101, 2009.

[8] Ottander, C., and Ekborg, M., "Students' Experience of Working with Socioscientific Issues - a Quantitative Study in Secondary School," Research in Science Education, vol. 42, no. 6, pp. 1147-1163, 2012.

[9] Tidemand, S. and Nielsen, J. A., "The role of socioscientific issues in biology teaching: from the perspective of teachers," International Journal of Science Education, vol. 39, no. 1, pp. 44-61, 2017.

[10] Rock T. and Wilson C., "Improving teaching through lesson study," Teacher Education Quarterly, pp. 77-92, 2005.

[11] Rahayu, P., Mulyani, S., and Miswadi, S. S., "Development of integrated science learning by using problem base learning models through lesson study," Jurnal Pendidikan IPA Indonesia, vol. 1, no. 1, pp. 63-70, 2012.

[12] European Commission, High Level Group on Science Education, European Commission. Science, and Economy, Science education now: A renewed pedagogy for the future of Europe, vol. 22845, Office for Official Publications of the European Communities, 2007.

[13] European Commission, Directorate-General for Employment, Employment and social developments in Europe 2011, vol. 1, Publications Office of the European Union, 2012.

[14] National Research Council, The aging mind: Opportunities in cognitive research. National Academies Press, 2000. 
[15] Aikenhead, G., "Towards a cultural view on quality science teaching," In The professional knowledge base of science teaching, Springer, Dordrecht, pp. 107-127, 2011.

[16] Rocard, M., "Science education now: A renewed pedagogy for the future of Europe," Brussel: High level group on science education, directorate general for research, Science, Economy and Science, European Commission, 2007.

[17] Lederman, N. G., Antink, A., and Bartos, S., "Nature of science, scientific inquiry, and socio-scientific issues arising from genetics: A pathway to developing a scientifically literate citizenry," Science and Education, vol. 23, no. 2, pp. 285-302, 2014.

[18] Liu, S. Y., Lin, C. S., and Tsai, C. C., "College students' scientific epistemological views and thinking patterns in socioscientific decision making," Science Education, vol. 95, no. 3, pp. 497-517, 2011.

[19] Hsu, Y. S. and Lin, S. S., "Prompting students to make socioscientific decisions: embedding metacognitive guidance in an e-learning environment," International Journal of Science Education, vol. 39, no. 7, pp. 964-979, 2017.

[20] Jho, H., Yoon, H. G., and Kim, M., "The relationship of science knowledge, attitude and decision making on socioscientific issues: The case study of students' debates on a nuclear power plant in Korea," Science \& Education, vol. 23, no. 5, pp. 1131-1151, 2014.

[21] Yenni, R., Hernani, and Widodo, A., "The implementation of integrated science teaching materials based socioscientific issues to improve students' scientific literacy for environmental pollution theme," AIP Conference Proceedings, AIP Publishing LLC, vol. 1848, no. 1, p. 060002, 2017.

[22] Rizal, H. P., P. Siahaan, and G. Yuliani., "Implementation of socioscientific issues instruction to fostering students' decision making based gender on environmental pollution," Journal of Physics Conference Series. IOP Publishing Ltd, vol. 812, no.1, pp. 1-6, 2017.

[23] Ottander, C., and Ekborg, M., "Students' experience of working with socioscientific issues-a quantitative study in secondary school," Research in Science Education, vol. 42, no. 6, pp. 1147-1163, 2012.

[24] Rudsberg, K., Öhman, J., and Östman, L., "Analyzing students' learning in classroom discussions about socioscientific issues," Science Education, vol. 97, no. 4, 594-620, 2013.

[25] Grace, M., Lee, Y. C., Asshoff, R., and Wallin, A., "Student decision-making about a globally familiar socioscientific issue: The value of sharing and comparing views with international counterparts," International Journal of Science Education, vol. 37, pp. 11, pp. 1855-1874, 2015.

[26] Åkerblom, D., and Lindahl, M., "Authenticity and the relevance of discourse and tabled worlds in secondary students' discussions of socioscientific issues," Teaching and Teacher Education, vol. 65, pp. 205-214, 2017.

[27] Eggert, S., Nitsch, A., Boone, W. J., Nückles, M., and Bögeholz, S., "Supporting students' learning and socioscientific reasoning about climate change-the effect of computer-based concept mapping scaffolds, Research in Science Education, vol. 47, no. 1, pp. 137-159, 2017.

[28] Tsai, C. Y., "The effect of online argumentation of socio-scientific issues on students' scientific competencies and sustainability attitudes," Computers \& Education, vol. 116, pp. 14-27, 2018.

[29] Steffen, B., and Hößle, C. "Assessing students' performances in decision-making: Coping strategies of biology teachers," Journal of Biological Education, vol. 51, no. 1, pp. 44-51, 2017.

[30] Sakschewski, M., Eggert, S., Schneider, S., and Bögeholz, S., "Students' Socioscientific Reasoning and Decisionmaking on Energy-related Issues-Development of a measurement instrument," International Journal of Science Education, vol. 36, no. 14, pp. 2291-2313, 2014.

[31] Böttcher, F., and Meisert, A., "Effects of direct and indirect instruction on fostering decision-making competence in socioscientific issues," Research in Science Education, vol. 43, no. 2, pp. 479-506, 2013.

[32] Lenz, L., and Willcox, M. K., "Issue-oriented science: using socioscientific issues to engage biology students," The american biology Teacher, vol. 74, no. 8, pp. 551-556, 2012.

[33] Yacoubian, H. A., "Scientific literacy for democratic decision-making," International Journal of Science Education, vol. 40, no. 3, pp. 308-327, 2018.

[34] Khishfe, R., "Nature of science and decision-making," International Journal of Science Education, vol. 34, no. 1, pp. 67-100, 2012.

[35] Morris, H., "Socioscientific issues and multidisciplinarity in school science textbooks," International Journal of Science Education, vol. 36, no. 7, pp. 1137-1158, 2014.

[36] Evagorou, M., Jimenez-Aleixandre, M. P., and Osborne, J., "Should we kill the grey squirrels?'A study exploring students' justifications and decision-making," International Journal of Science Education, vol. 34, no. 3, pp. 401-428, 2012.

[37] Sadler, T. D., Romine, W. L., and Topçu, M. S., "Learning science content through socio-scientific issues-based instruction: A multi-level assessment study," International Journal of Science Education, vol. 38, no. 10, pp. 1622-1635, 2016.

[38] Hodson, D., "Nature of science in the science curriculum: Origin, development, implications and shifting emphases," International handbook of research in history, philosophy and science teaching, Springer, Dordrecht, pp. 911-970, 2014.

[39] Martín-Gámez, C., and Erduran, S., "Understanding argumentation about socio-scientific issues on energy: A quantitative study with primary pre-service teachers in Spain," Research in Science \& Technological Education, vol. 36, no. 4, pp. 463-483, 2018.

[40] Tekin, N., Aslan, O., and Yilmaz, S., "Research Trends on Socioscientific Issues: A Content Analysis of Publications in Selected Science Education Journals," Journal of Education and Training Studies, vol. 4, no. 9, pp. 16-24, 2016.

Int. J. Eval. \& Res. Educ. Vol. 9, No. 2, June 2020: 311 - 317 
[41] Siribunnam, S., Nuangchalerm, P., and Jansawang, N., "Socio-scientific Decision Making in the Science Classroom," International Journal for Cross-Disciplinary Subjects in Education (IJCDSE), vol. 5, no. 4, pp. 1777-1782, 2014.

[42] Yahaya, J. M., Zain, A. N., and Karpudewan, M., "Understanding Socioscientific Issues in a Low Literate Society for the Achievement of the Millennium Development Goals," International Journal of Social, Management, Economics and Business Engineering, vol. 6, no. 12, pp. 692-695, 2012.

[43] Chowning, J. T., Griswold, J. C., Kovarik, D. N., and Collins, L. J., "Fostering critical thinking, reasoning, and argumentation skills through bioethics education," PloS one, vol. 7, no. 5, 2012.

[44] Iordanou, K., and Constantinou, C. P., "Developing pre-service teachers' evidence-based argumentation skills on socio-scientific issues," Learning and Instruction, vol. 34, pp. 42-57, 2014.

[45] Atabey, N. and Topcu, S., "The effects of socioscientific issues based instruction on middle school students' argumentation quality," Journal of Education and Practice, vol. 8, no. 36, pp. 61-71, 2018.

[46] Kilinc, A., Demiral, U., and Kartal, T., "Resistance to dialogic discourse in SSI teaching: The effects of an argumentation-based workshop, teaching practicum, and induction on a preservice science teacher," Journal of Research in Science Teaching, vol. 54, no. 6, pp. 764-789, 2017.

[47] D. Bayram-Jacobs, et al., "Science teachers' pedagogical content knowledge development during enactment of socioscientific curriculum materials," Journal of Research in Science Teaching, vol. 56, no. 9, pp. 1207-1233, 2019.

[48] Gutierez, S. B., "Integrating Socio-Scientific Issues to Enhance the Bioethical Decision-Making Skills of High School Students," International Education Studies, vol. 8, no. 1, pp. 142-151, 2015.

[49] Rubini, B., Ardianto, D., Setyaningsih, S., and Sariningrum, A., "Using socio-scientific issues in problem based learning to enhance science literacy," Journal of Physics: Conference Series, IOP Publishing, vol. 1233, no. 1, p. 012073, 2019.

[50] Gutierez, S. B., "Integrating Socio-Scientific Issues to Enhance the Bioethical Decision-Making Skills of High School Students," International Education Studies, vol. 8, no. 1, pp. 142-151, 2015.

[51] Saunders, K. J. and Rennie, L. J., "A Pedagogical Model for Ethical Inquiry into Socioscientific Issues In Science," Res Sci Educ, vol. 43, pp. 253-274, 2013.

[52] Levinson, R., "Towards a theoretical framework for teaching controversial socio-scientific issues," International Journal of Science Education, vol. 28, no. 10, pp. 1201-1224, 2006.

[53] Chong, W. H. and Kong, C. A. "Teacher collaborative learning and teacher self-efficacy: The case of lesson study," The journal of experimental education, vol. 80, no. 3, pp. 263-283, 2012.

[54] Winsløw, C., "A comparative perspective on teacher collaboration: The cases of lesson study in Japan and of multidisciplinary teaching in Denmark," In from Text to'Lived'Resources, Springer, Dordrecht, pp. 291-304, 2011.

[55] Lewis, C. C., Perry, R. R., and Hurd, J., "Improving mathematics instruction through lesson study: A theoretical model and North American case" Journal of mathematics teacher education, vol. 12, no. 4, pp. 285-304, 2009.

[56] Makinae, N., "The origin of lesson study in Japan," The 5th East Asia Regional Conference on Mathematics Education: In Search of Excellence in Mathematics Education, Tokyo, vol. 2, pp. 140-47, 2010.

[57] Fernández, M. L., "Learning through microteaching lesson study in teacher preparation," Action in Teacher Education, vol. 26, no. 4, pp. 37-47, 2005.

[58] Zeichner, K., "The turn once again toward practice-based teacher education," Journal of teacher education, vol. 63 , no. 5, pp. 376-382, 2012. 